\title{
TERMOSKOP DAN PENDINGIN UDARA SEDERHANA: PENGEMBANGAN ALAT PERAGA FISIKA UNTUK PEMBELAJARAN FISIKA
}

\section{SIMPLE TERMOSCOPES AND AIR CONDITIONER: DEVELOPMENT OF PHYSICAL ASSEMBLY TOOLS FOR PHYSICAL LEARNING}

\author{
Fitri Anggi Marscella ${ }^{1}$, Happy Komikesari ${ }^{2}$, Jamal Fakhri ${ }^{3}$, Pramita Sylvia Dewi ${ }^{4}$ \\ ${ }^{1}$ SD N 1 Sidoasri Lampung Selatan \\ ${ }^{2}$ Prodi Pendidikan Fisika Fakultas Tarbiyah dan Keguruan Universitas Islam Negeri Raden Intan Lampung \\ ${ }^{3}$ Program Pascasarjana Universitas Islam Negeri Raden Intan Lampung \\ ${ }^{4}$ Jurusan Pendidikan Guru Sekolah Dasar Universitas Lampung \\ E-mail: fitrianggi.iain@gmail.com
}

\begin{abstract}
This research is background because learners do not understand the concept of physics with daily events, there is no tool to support the teaching and learning process. The use of simple physics props is expected to improve the learning outcomes of learners and can understand the concept by connecting the daily events in human life in physics. This research uses qualitative and quantitative approach, while the type of this research is research and development. Data collection technique is using questionnaire. Data analysis techniques to test the feasibility of props using Likert scale. Based on the results of data analysis using the likert scale statistic test, SMA Negeri 1 Sidomulyo get the percentage of eligibility of $82.925 \%$ "Very Good" category, SMA Negeri 1 Candipuro get the feasibility percentage of $82.7 \%$ "Very Good" category and SMA Muhammadiyah 1 Sidomulyo get percentage Eligibility of $83.3 \%$ "Very Good" category. The average result of the students' responses in the three schools earned a feasibility percentage of $84.2 \%$ of the "Excellent" category.
\end{abstract}

Keywords: research and development, physical assembly tools

Abstrak: Penelitian ini berlatarbelakang karena peserta didik kurang memahami konsep fisika dengan kejadian sehari-hari, tidak ada alat untuk menunjang proses belajar mengajar. Penggunaan alat peraga fisika sederhana diharapkan mampu meningkatkan hasil belajar peserta didik dan bisa memahami konsep dengan menghubungkan kejadian sehari-hari dalam kehidupan manusia dalam mata pelajaran fisika Penelitian ini menggunakan pendekatan kualitatif dan kuantitatif, adapun jenis penelitian ini yaitu penelitian dan pengembangan. Teknik pengumpulan data yaitu menggunakan angket. Teknik analisis data untuk menguji kelayakan alat peraga menggunakan skala likert.. Berdasarkan hasil analisis data menggunakan uji statistik skala likert, SMA Negeri 1 Sidomulyo mendapatkan persentase kelayakan sebesar $82,925 \%$ kategori "Sangat Baik", SMA Negeri 1 Candipuro mendapatkan persentase kelayakan sebesar 82,7\% kategori "Sangat Baik" dan SMA Muhammadiyah 1 Sidomulyo mendapatkan persentase kelayakan sebesar 83,3\% kategori "Sangat Baik". Hasil rata-rata tanggapan peserta didik ditiga sekolah mendapatkan persentase kelayakan sebesar 84,2\% kategori "Sangat Baik"

C 2019 Unit Riset dan Publikasi Ilmiah FTK UIN Raden Intan Lampung

Kata Kunci: penelitian dan pengembangan, alat peraga fisika

\section{PENDAHULUAN}

IPA mempelajari alam semesta, benda-benda yang ada dipermukaan bumi, di dalam perut bumi dan di luar angkasa, baik yang dapat diamati indera maupun yang tidak dapat diamati dengan indera. IPA atau ilmu kealaman adalah ilu tentang dunia zat, baik makhluk hidup
Comment [U1]: Cantumkan tujuan penelitian 
maupun benda mati yang diamati. (Trianto, 2012).

Sains terbagi atas beberapa cabang ilmu, diantaranya adalah fisika. Fisika banyak diimplementasi dalam kehidupan sehari-hari seperti alat elektronik, kendaraan dan sebagainya. Fisika merupakan salah satu pilar utama ilmu pengetahuan dan teknologi yang memberikan pemahaman mengenai fenomena alam, yang mempelajari bendabenda di alam, gejala-gejala, kejadiankejadian alam, serta interaksi dari bendabenda di alam tersebut. Fisika juga merupakan sekumpulan fakta, konsep, hukum/prinsip, persamaan dan teori yang harus dipelajari dan dipahami. (Jumiati, 2016).

Mempelajari materi fisika membutuhkan pemahaman konsep yang kuat dan membutuhkan alat praktikum sebagai sarana pendukung dalam proses belajar mengajar. Materi yang dipelajari dalam fisika adalah pengukuran, pemuaian, kalor, listrik dan magnet, tekanan udara, tata surya, gerak dan materi lainnya. Materi-materi tersebut berhubungan erat dengan apa yang digunakan dalam kehidupan sehari-hari. Banyak di sekitar kita yang bisa dijadikan sebagai alat praktikum untuk mempermudah memahami tentang ilmu fisika. Dalam mata pelajaran fisika tidak hanya konsep- konsep teori saja yang dipelajari dan diketahui namun bisa dipraktekkan, untuk mendukung praktek tersebut membutuhkan alat praktikum. (Jumiati, 2016).

Berkaitan dengan permasalahan tersebut, maka perlu dikembangkan suatu alat peraga sederhana fisika sebagai media pembelajaran. Penting untuk melakukan penelitian pengembangan berbentuk R\&D (research and development) untuk mengembangkan alat peraga guna menunjang proses pembelajaran. Calon guru hendaknya bisa menciptakan situasi yang menarik dan memotivasi siswa untuk lebih semangat dan tertarik dalam pembelajaran menggunakan alat-alat yang menarik agar siswa dapat memahami teori yang disampaikan. Upaya menarik minat siswa dan untuk meningkatkan siswa memahami pelajaran, seorang guru hendaknya dapat berpikir lebih kreatif misalnya membuat alat peraga sederhana dari barang yang sederhana namun besar manfaatnya.

Penggunaan alat peraga sudah diterapkan di sekolah-sekolah, tetapi alatnya terbatas, tetapi guru tidak menerapkan alat peraga sepenuhnya dikelas. Guru tidak mau ribet dalam penggunaanya, serta tidak mau ribet membuat penuntun praktikum mengenai alat peraga. Dasar proses belajar adalah pengalaman dan proses belajar yang efektif serta permanen diperoleh dari pengalaman yang bersifat konkret dan langsung. Pengalaman langsung dapat diperoleh ketika siswa menggunakan atau secara langsung berhadapan dengan alat peraga.

Hal tersebut dapat terealisasi, maka diperlukan alat atau bahan yang dapat menanamkan konsep fisika peserta didik seperti sebuah alat peraga. Sebagian besar sekolah memiliki lab yang menunjang tetapi tidak digunakan sebaikbaiknya. Berarti secara otomatis sebagian besar sekolah memiliki sebuah alat yang menunjang kegiatan percobaan-percobaan fisika tetapi alat yang dipergunakan masih terbatas. Peserta didik akan menempatkan konsep-konsep dalam sistem memori jangka panjang dan dapat menggunakanya untuk perfikir dalam tingkatan yang lebih tinggi seperti pemecahan masalah dan berfikir kreatif. Proses pembelajaran ini akan berhasil, perlu sesuatu yang menarik dan mudah di mengerti oleh peserta didik. Hendaknya sebagai calon pendidik bisa menciptakan situasi yang menarik dan memotivasi peserta didik untuk lebih semangat dan tertarik dalam pembelajaran. 
Indonesian Journal of Science and Mathematics Education 02 (3) (2019) X

\begin{tabular}{l|c}
\hline Fitri Anggi Marscella, dkk & Termoskop dan Pendingin Udara ......
\end{tabular}

Segala sesuatu yang masih bersifat abstrak, kemudian dikonkretkan dengan menggunakan alat agar dapat dijangkau dengan pikiran yang sederhana dan dapat dilihat, dipandang, dan dirasakan. (Arsyad, 2003). Melalui penelitian ini, penulis bermaksud mengembangkan alat peraga sederhana yang terbuat dari bahanbahan yang terjangkau. Pengembangan alat peraga sederhana ini diharapkan dapat meningkatkan mutu pendidikan dan pemahaman konsep pada peserta didik.

Berdasarkan pemaparan masalahmasalah di atas, peneliti tertarik untuk mengembangkan media pembelajaran dengan judul "Pengembangan Alat Peraga Fisika Sederhana Berupa Termoskop Dan Ac Pendingin Sederhana Untuk Pembelajaran Materi Termodinamika Kelas XI SMA" dengan sajian yang lebih menarik khususnya untuk kalangan peserta didik Sekolah Menengah Atas.

\section{LANDASAN TEORI}

Kata media berasal dari bahasa Latin medius yang secara harafiah berarti 'tengah', 'perantara' atau 'pengantar'. Dalam bahasa Arab media adalah perantara atau pengantar pesan dari pengirim kepada penerima pesan. Gerlach \& Ely mengatakan bahwa media apabila dipahami secara garis besar adalah manusia, materi, atau kejadian yang membangun kondisi yang membuat siswa mampu memperoleh pengetahuan, keterampilan, atau sikap. Dalam pengertian ini, guru, buku teks dan lingkungan sekolah merupakan media. Secara lebih khusus, pengertian media dalam proses belajar mengajar cenderung diartikan sebagai alat-alat grafis, photografis, atau elektronis untuk menangkap, memproses, dan menyusun kembali informasi visual atau verbal. (Arsyad, 2003).

Media adalah sebagai sumber belajar, maka secara luas media dapat diartikan dengan manusia, benda, ataupun peristiwa yang memungkinkan anak didik memperoleh pengetahuan dan keterampilan. Dalam proses belajar mengajar kehadiran media mempunyai arti yang cukup prnting. Karena dalam kegiatan tersebut ketidakjelasan bahan yang disampaikan dapat dibantu dengan menghadirkan media sebagai perantara. Kerumitan bahan yang akan disampaikan kepada anak didik dapat disederhanakan dengan bantuan media. Media dapat mewakili apa yang kurang mampu guru ucapkan melalui kata-kata atau kalimat tertentu. Bahkan keabstrakan bahan dapat dikonkretkan dengan kehadiran media. Dengan demikian, anak didik lebih mudah mencerna bahan daripada tanpa bantuan media. (Djamharah, Zain, 2013).

Alat Peraga adalah media alat bantu pembelajaran, dan segala macam benda yang digunakan untuk memperagakan materi pelajaran. Alat peraga disini pengertian bahwa segala sesuatu yang masih bersifat abstrak, kemudian dikonkretkan dengan menggunakan alat agar dapat dijangkau dengan pikiran yang sederhana dan dapat dilihat, dipandang, dan dirasakan. Dengan demikian, alat peraga lebih khusus dari media dan teknologi pembelajaran karena berfungsi hanya untuk memperagakan materi pelajaran yang bersifat abstrak. (Arsyad, 2003). Alat peraga IPA mempunyai peranan yang sangat penting dalam pembelajaran, yaitu untuk menjelaskan konsep, sehingga siswa memperoleh kemudahan dalam memahami hal-hal yang dikemukakan guru, memantapkan penguasaan materi yang ada hubungannya dengan bahan yang dipelajari, dan mengembangkan keterampilan.

Jadi kesimpulannya alat peraga ialah alat-alat yang digunakan guru yang berfungsi membantu guru dalam proses mengajarnya dan membantu peserta didik dalam proses belajarnya.

\section{Termoskop Sederhana}

Comment [U2]: Perkuat latar belakang dengan temuan lapangan, kaitkan masalah dengan teori yg relevan 
Alat praktikum termoskop adalah alat yang digunakan untuk mengetahui adanya radiasi kalor atau energi pancaran kalor dan termoskop dapat dipakai untuk menyelidiki sifat pancaran dari permukaan zat. Termoskop terdiri atas dua bola lampu hitam dan putih yang dihubungkan dengan pipa $\mathrm{U}$, pipa $\mathrm{U}$ ini berisi alkohol. (Jumiati, 2016).

\section{AC Pendingin Sederhana}

Mesin pendingin adalah mesin yang berfungsi untuk mendinginkan suatu zat sehingga suhunya lebih rendah daripada suhu lingkungan. Komponen utama mesin pendingin adalah kompresor, kondensor, alat ekspansi, evaporator dan refrigeran. Namun berbeda dengan pendingin sederhana yang dimaksud pada penelitian ini. Alat ini terbuat dari bahan sederhana yang ada disekitar siswa. Media pendingin dapat berupa es basah, es kering, air dingin, es ditambah garam, air laut yang didinginkan dengan es, air laut yang didinginkan secara mekanis dan udara dingin. Dalam pembuatan pendingin sederhana ini media pendingin yang digunakan berupa es batu.

Alat peraga dari bahan sederhana atau bahan bekas selain murah ternyata juga dapat meningkatkan prestasi belajar siswa. Pendingin sederhana ini selain diharapkan dapat membuat siswa lebih paham mengenai perpindahan panas, juga diharapkan dapat menyajikan contoh nyata konsep fisika yang dapat menghasilkan suatu alat pengembangan teknologi tanpa listrik. Ada beberapa keuntungan menggunakan alat ini diantaranya adalah: harganya murah, bahan mudah diperoleh dan dapat meningkatkan kreativitas guru serta siswa. (Kusrinaningrum, Sutikno, \& Masturi, 2015).

Berikut adalah perencanaan pengembangan termoskop sederhana sebagai alat peraga fisika yang dikembangkan:
1. Pengumpulan alat dan bahan yang digunakan untuk membuat alat peraga pembelajaran fisika termoskop sederhana seperti: bohlam utuh, isolasi hitam, plastisin/lilin mainan, papan kayu, selang bening, alkohol, pewarna merah, bohlam yang sudah dibersihkan fitingnya, paku, palu, bor, kabel, kardus, paku klem.

2. Merangkai papan ukuran $22 \times 16 \mathrm{~cm}$ dan papan ukuran $22 \times 8 \mathrm{~cm}$ diatas dan dibawah

3. Paku bagian atas dan bagian bawah papan

4. Setelah dipaku, bor bagian atas papan, bor bagian sisi kanan dan sisi kiri

5. Bohlam yang sudah dibersihkan fitingnya lalu piloks salah satu bohlam dengan warna hitam.

6. Memasang selang dipapan yang sudah dibor dengan membentuk huruf U, lalu keratkan dengan paku klem.

7. Mengisi selang dengan alcohol yang sudah diberi pewarna merah.

8. Memasang kedua bohlam lampu diatas selang tersebut.Memastikan lubang tertutup rapat dengan menggunakan plastisin dan isolasi.

9. Memasang lampu dengan pitingan lalu kaitkan dengan kabel.

10. Memasang lampu dipermukaan dalam kardus, beserta kabel seperti digantung.

11. Membungkus kardus agar terlihat lebih menarik

12. Setelah itu, cara kerja alat ini yaitu dengan menghidupkan lampu.

13. Selang beberapa menit kemudian alkohol pada selang $U$ dibawah bohlam hitam terdorong kebawah dan alkohol dibawah bohlam bening naik keatas.

14. Itu berarti alat dapat bekerja dan digunakan.

Berikut adalah perencanaan pengembangan $\mathrm{AC}$ pendingin sederhana 
Indonesian Journal of Science and Mathematics Education 02 (3) (2019) X

sebagai alat peraga fisika yang dikembangkan:

1. Mengumpulkan alat dan bahan seperti: steroform, cutter, lem kayu, kipas 2 buah, esbatu, penggaris, triplek, termometer.

2. Memotong tripleks dan sterofom menggunakan cutter dengan ukuran yang sama lalu rekatkan menggunakan lem kayu (bagian bawah)

3. Untuk bagian samping kanan dan kiri ukurannya sama

4. Untuk bagian depan tempelkan 2 buah kipas pendingin

5. Untuk bagian belakang dibuat lubang angin persegi panjang

6. Untuk bagian atas dibuat pegangan agar bisa dibuka

7. Cara kerja alat ini dengan memasukkan beberapa es batu lalu menyalurkan kabel di Laptop atau langsung ke saluran listrik.

8. Alat akan bekerja dengan mengeluarkan udara dingin lewat lubang angin.

9. Setelah itu kita menghitung suhu sebelum dan sesudah dimasukkan es batu.
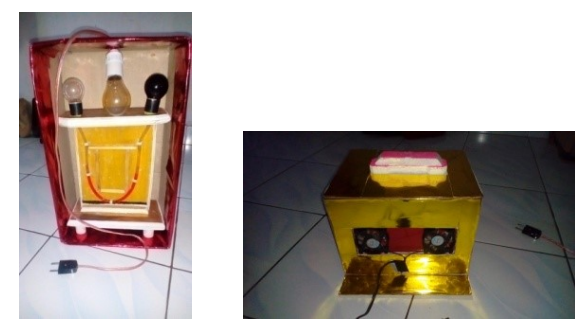

Gambar 1. Alat Peraga Termoskop dan AC pendingin Sederhana

Usaha dapat diperoleh dengan mengubah keadaan suatu gas. Dalam keadaan normal, piston akan diam pada ketinggian $h_{l}$. Ketika suhu gas di dalam tabung bertambah tinggi, gas akan memuai. Jika tekanan udara luar tetap (tekanan dari atas piston), maka piston akan bergerak akibat pemuaian gas, dan piston berada pada ketinggian $h_{2}$. Apakah yang menyebabkan piston bergerak? Jika suhu gas meningkat maka tekannya pun meningkat. Gerakan piston ini disebabkan oleh gaya tekan gas terhadap piston. Besarnya gaya yang dilakukan gas pada piston dinyatakan dalam persamaaan: (Supardianningsih, 2015)

$$
F=P x A
$$

Keterangan:

$P=$ tekanan gas $\left(\mathrm{N} / \mathrm{m}^{2}\right)$

$A=$ luas penampang piston $\left(\mathrm{m}^{2}\right)$

$F=$ besar gaya $(\mathrm{N})$

Contoh dari mesin pendingin carnot antara lain mesin pendingin ruangan dan lemari es. Siklus mesin pendingin carnot merupakan kebalikan siklus mesin kalor carnot karena siklusnya reversible (dapat balik). Usaha pada mesin pendingin carnot dituliskan:

$$
W=Q_{t}-Q_{r}
$$

Karakteristik pada mesin pendingin dinyatakan dalam koefisien performansi atau koefisien kinerja yang simbolnya $K_{d}$. Koefisien kinerja didefinisikan sebagai perbandingan antara kalor yang dipindahkan dengan usaha yang dilakukan sistem. Secara matematis dapat ditulis: (Supardianingsih 2015).

$$
K_{d}=\frac{1}{\eta}-1
$$

\section{METODE PENELITIAN}

Pada penelitian ini menggunakan metode penelitian dan pengembangan Research and Development (R\&D). Sugiono mengatakan metode penelitian Research and Development (R\&D) adalah metode penelitian yang digunakan untuk mengembangkan atau menghasilkan produk tertentu, dan menguji keefektifan produk tersebut. (Sugiyono, 2014).

Penelitian yang dilakukan ini menggunakan prosedur penelitian pengembangan yang telah dimodifikasi oleh Sugiono. Untuk dapat menghasilkan produk alat peraga sederhana tertentu digunakan penelitian yang bersifat 
analisis kebutuhan dan untuk menguji keefektifan produk alat peraga sederhana tersebut supaya dapat berfungsi di masyarakat luas, maka diperlukan penelitian untuk menguji keefektifan produk tersebut. Jadi penelitian dan pengembangan bersifat bertahap. (Sugiyono, 2014).

Langkah langkah penelitian dan pengembangan ditunjukan pada bagan berikut: (Sugiyono, 2014)

1. Potensi dan Masalah

2. Pengumpulan Data

3. Desain Produk

4. Validasi Desain

5. Revisi Desain

6. Uji Coba Produk

7. Revisi Produk

8. Uji Coba Pemakaian

9. Revisi Produk

10. Produksi Massal

Pada penelitian ini peneliti menggunakan model Borg and Gall yang telah dimodifikasi oleh Sugiono. Dalam penelitian dan pengembangan yang telah ditunjukan dibutuhkan sepuluh langkah pengembangan untuk menghasilkan produk akhir yang siap untuk diterapkan dalam lembaga pendidikan. Tetapi, peneliti membatasi langkah-langkah penelitian pengembangan dari sepuluh langkah menjadi tujuh langkah dikarenakan mengingat waktu yang tersedia dan kesempatan yang terbatas. Langkah-langkah penelitian dan pengembangan adalah sebagai berikut: (Emzir, 2013)

1. Mengidentifikasi Potensi dan Masalah (observasi kebutuhan kepada guru dan peserta didik)

2. Pengumpulan Data (melakukan pra penelitian)

3. Desain Produk (membuat produk awal yang akan dikembangkan)

4. Validasi Desain (validasi kepada ahli materi dan media)

5. Revisi Desain (perbaikan desain sesuai kritik dan saran validator)
6. Uji Coba Produk kepada peserta didik

7. Revisi Produk setelah uji coba

Pengumpulan data menggunakan instrumen lembar validasi berupa angket menggunakan skala likert yang digunakan untuk mengetahui apakah instrumen yang telah dirancang valid atau tidak.

Prosedur pengumpulan data dalam model penelitian pengembangan ini instrumen angket. Instrumen angket digunakan untuk menganalisis kebutuhan dengan mengetahui data nilai rata-rata kelas, ketersediaan sumber, alat peraga, fasilitas pembelajaran serta laboratorium fisika. Instrumen angket uji ahli digunakan untuk mengumpulkan data tentang kelayakan produk berdasarkan kesesuaian media dan isi materi termodinamika pada produk yang telah dikembangkan; instrumen angket respon pengguna digunakan untuk mengumpulkan data tingkat kemenarikan, kemudahan, dan kemanfaatan; dan data hasil tes digunakan untuk mengetahui tingkat keefektifan produk.

Teknik analisis data pada penelitian ini yaitu menggunakan teknik analisis deskritif kualitatif dan kuantitatif. Data kualitatif berupa masukan validator pada tahap validasi, masukan dari ahli media, ahli materi dan juga guru fisika.

Tabel 5. Kategori Kualitas (Eko Putro, 2012)

\begin{tabular}{ll}
\hline Kategori & Keterangan \\
\hline SB & Sangat Baik \\
B & Baik \\
CB & Cukup Baik \\
KB & Kurang Baik \\
TB & Tidak Baik \\
\hline
\end{tabular}

Tabel 6. Pedoman Pemberian Skor Skala Likert

\begin{tabular}{ll}
\multicolumn{2}{c}{ (Eko Putro, 2012) } \\
\hline Kategori & Skor \\
\hline Sangat Baik (BS) & 5 \\
Baik (B) & 4 \\
Cukup Baik (CB) & 3 \\
Kurang Baik (KB) & 2 \\
Tidak Baik (TB) & 1 \\
\hline
\end{tabular}

Tabel 7. Skala Kuantitatif (Nanang Khoirudin 2013)
Comment [U3]: Jelaskan instruen yang digunakan 
Indonesian Journal of Science and Mathematics Education 02 (3) (2019) X

\begin{tabular}{ll}
\hline Fitri Anggi Marscella, dkk & \\
& \\
\hline Kriteria Kuantitatif & Kategori \\
\hline $81 \%-100 \%$ & Sangat Baik \\
$61 \%-80 \%$ & Baik \\
$41 \%-60 \%$ & Cukup Baik \\
$21 \%-40 \%$ & Kurang Baik \\
$<21 \%$ & Tidak Baik \\
\hline
\end{tabular}

Nilai keseluruhan dari alat peraga pembelajaran fisika ini ditentukan dengan menghitung skor rata-rata seluruh kreteria penilaian, kemudian data yang diperoleh dibuah menjadi data kualitatif sesuai dengan kriteria penilaian.

\section{HASIL DAN PEMBAHASAN}

Dalam penelitian ini, peneliti menggunakan tiga sekolah yaitu SMA Negeri 1 Sidomulyo kelas XI IPA 5, SMA Negeri 1 Candipuro kelas XI IPA 2 dan SMA Muhammadiyah 1 Sidomulyo kels XI IPA 2. Penelitian ini bertujuan untuk mengetahui cara pengembangan alat peraga fisika sederhana serta untuk mengetahui kelayakan alat peraga fisika sederhana materi termodinamika.

Berdasarkan penelitian yang telah dilakukan didapatkan hasil sebagai berikut:

\section{Hasil validasi produk oleh ahli materi tahap I}

Hasil validasi oleh ahli materi mencakup 3 aspek penilaian yaitu keterkaitan alat peraga dengan bahan ajar, nilai pendidikan, dan konten fisika. Hasil penilaian dari 3 ahli materi mendapatkan nilai rata-rata sebesar 2,8 dengan kriteria kelayakan sebesar 54,3\%. Kategori penilaian adalah "Cukup Baik". Saran atau masukan yang diberikan validator yaitu alat peraga belum bisa mengungkap materi suhu kalor, tetapi lebih ke materi termodinamika, bahan ajar tidak ada untuk divalidasi. Hal ini berarti alat peraga belum sesuai dengan materi pembelajaran.

\section{Hasil validasi produk oleh ahli materi tahap II}

Hasil validasi oleh ahli materi mencakup 3 aspek penilaian yaitu keterkaitan alat peraga dengan bahan ajar, nilai pendidikan, dan konten fisika. Hasil penilaian dari 3 ahli materi mendapatkan nilai rata-rata sebesar 3,78 dengan kriteria kelayakan sebesar 75,9\%. Kategori penilaian adalah "Baik". Saran atau masukan sudah diperbaiki hal ini berarti alat peraga sudah sesuai dengan materi pembelajaran dan layak untuk digunakan.

\section{Hasil validasi ahli media tahap I}

Pada validasi yang dilakukan oleh ahli media alat peraga sudah layak digunakan dalam pembelajaran tetapi ada beberapa komponen yang harus diperbaiki. Hal ini terlihat dari hasil penilaian yang dilakukan oleh validator ahli media. Validasi ahli media ini mecakup 5 aspek yaitu efesiensi alat peraga, keakuratan alat peraga, estetika, ketahanan alat dan keamanan bagi peserta didik. Hasil penilaian pada tahap I ini mendapatkan nilai rata-rata 3,75 dengan kriteria kelayakan sebesar 75,34\% dan kategori penilaian adalah "Baik". Salah satu bagian yang diperbaiki adalah bagian untuk termoskop sederhana menambahkan sebuah alat yang bisa menghantarkan panas dengan cepat, agar panas tidak tersebar, jadi fokus terhadap lampu warna, pekatkan lagi warna hitam pada bohlam hitam dan beri penanda pada pipet cairan. Untuk AC pendingin sederhana kipasnya terbalik ,sambungkan kelistrik dan membuat alat agar terlihat lebih cantik dan lebih menarik untuk dilihat.

\section{Hasil validasi ahli media tahap II}

Pada validasi yang dilakukan oleh ahli media alat peraga sudah layak digunakan dalam pembelajaran tetapi ada beberapa komponen yang harus diperbaiki. Hal ini terlihat dari hasil penilaian yang dilakukan oleh validator ahli media. Validasi ahli media ini mecakup 5 aspek yaitu efesiensi alat 
peraga, keakuratan alat peraga, estetika, ketahanan alat dan keamanan bagi peserta didik. Hasil penilaian pada tahap II ini mendapatkan nilai rata-rata 4,40 dengan kriteria kelayakan sebesar $83,68 \%$ dan kategori penilaian adalah "Sangat Baik".

Hasil validasi produk yang telah dikembangkan menunjukan bahwa alat peraga sudah baik tetapi perlu ada perbaikan-perbaikan agar lebih layak dan lebih baik ketika digunakan sebagai alat peraga pembelajaran. Produk yang telah direvisi sudah sesuai dengan saran atau masukan dari para validator. Hasil revisi ahli media tahap I ada beberapa saran atau masukan. Saran teserbut sudah diperbaiki. Setelah validasi dilakukan maka produk siap diuji coba.

\section{Hasil Uji Coba Lapangan ditiga sekolah}

Persentase penilaian uji coba lapangan di SMA N 1 Sidomulyo. Penilaian asepek 1 penampilan fisik alat peraga mendapatkan persentase kelayakan $72,2 \%$ dengan kategori baik. Penilaian aspek 2 tentang motivasi belajar dan pemahaman konsep mendapatkan persentase kelayakan $75 \%$ dengan kategori baik. Penilaian aspek 3 tentang pengoprasian alat peraga mendapat persentase kelayakan sebesar 93,5\% dengan kategori sangat baik dan penilaian aspek 4 tentang kualitas mendapatkan persentase kelayakan $95 \%$ dengan kategori sangat baik. Rerata dari hasil tanggapan peserta didik SMA N 1 Sidomulyo mendapatkan persentase $83,925 \%$ dengan kategori sangat baik.

Persentase penilaian uji coba lapangan di SMA N 1 Candipuro. Penilaian asepek 1 penampilan fisik alat peraga mendapat persentase kelayakan $68,3 \%$ dengan kategori baik. Penilaian aspek 2 tentang motivasi belajar dan pemahaan konsep mendapatkan persentase kelayakan 75,4\% dengan kategori baik. Penilaian aspek 3 tentang pengoprasian alat peraga mendapat persentase kelayakan sebesar 92,6\% dengan kategori sangat baik dan penilaian aspek 4 tentang kualitas alat peraga mendapatkan persentase kelayakan 94,6\% dengan kategori sangat baik. Rerata hasil tanggapan uji coba lapangan SMA N 1 Candipuro mendapatkan persentase $82,7 \%$ dengan kategori sangat baik.

Persentase penilaian uji coba lapangan di SMA Muhammadiyah 1 Sidomulyo. Penilaian asepek 1 penampilan fisik alat peraga mendapat persentase kelayakan 88,2\% dengan kategori sangat baik. Penilaian aspek 2 tentang motivasi belajar mendapatkan persentase kelayakan $74,8 \%$ dengan kategori baik. Penilaian aspek 3 tentang pengoprasian alat peraga mendapat persentase kelayakan sebesar 78,4\% dengan kategori baik dan penilaian aspek 4 tentang kualitas alat peraga mendapatkan persentase kelayakan 91,8\% dengan kategori sangat baik. Rerata hasil tanggapan uji coba lapangan SMA Muhammadiyah $\quad 1 \quad$ Sidomulyo mendapatkan persentase kelayakan 83,3\% dengan kategori sangat baik.

Persentase penilaian uji coba lapangan di tiga sekolah. Penilaian asepek 1 penampilan fisik alat peraga mendapat persentase kelayakan $76 \%$ dengan kategori baik. Penilaian aspek 2 tentang motivasi belajar dan pemahaman konsep mendapatkan persentase kelayakan 73\% dengan kategori baik. Penilaian aspek 3 tentang pengoprasian alat peraga mendapat persentase kelayakan sebesar $88,3 \%$ dengan kategori sangat baik dan penilaian aspek 4 tentang kualitas alat peraga mendapatkan persentase kelayakan $99,4 \%$ dengan kategori sangat baik. Rerata hasil tanggapan peserta didik di tiga sekolah mendapatkan persentase kelayakan $84,2 \%$ dengan kategori sangat baik.

\section{Hasil Tanggapan Respon Pendidik ditiga sekolah}


Indonesian Journal of Science and Mathematics Education 02 (3) (2019) X Fitri Anggi Marscella, dkk

Persentase penilaian yang dilakukan oleh pendidik di tiga sekolah. Penilaian yang diberikan meliputi 8 aspek.. Data hasil penilaian dari tiga pendidik tersebut dapat diketahui pada aspek 1 tentang keterkaitan alat peraga dengan bahan ajar mendapatkan persentase kelayakan 96,7\% dengan kategori sangat baik. Pada aspek 2 penilaian tentang aspek nilai pendidikan mendapatkan persentase kelayakan 89,3\% dengan kategori sangat baik. Pada aspek 3 penilaian tentang efisiensi alat peraga mendapatkan persentase kelayakan $85 \%$ dengan kategori sangat baik. Pada aspek 4 penilaian tentang konten isi fisika mendapatkan persentase kelayakan 93,3\% dengan kategori sangat baik. Pada aspek 5 tentang keakuratan alat peraga mendapatkan persentase kelayakan 88,9\% dengan kategori sangat baik. Pada aspek 6 tentang estetika mendapatkan persentase kelayakan 91,1\% dengan kategori sangat baik. Pada aspek 7 tentang ketahanan alat mendapatkan persentase kelayakan 100\% dengan kategori sangat baik. Pada aspek 8 tentang keamanan bagi peserta didik mendapatkan persentase kelayakan 100\% dengan kategori sangat baik. Dengan ratarata persentase kelayakan sebesar 93\% dengan kategori sangat baik.

\section{KESIMPULAN}

Kesimpulan yang dapat diambil dari penelitian dan pengembangan ini adalah sebagai berikut: Pengembangan Alat Peraga Sederhana Fisika pada Mata Pelajaran Fisika Pokok Bahasan Termodinamika Kelas XI SMA dilakukan dengan mengadaptasi dari metode research and development/R\&D). Menurut Sugiyono melalui tahapantahapan Studi Pendahuluan, Perencanaan Produk Awal, Validasi Produk Awal, Revisi Produk awal, Uji Coba terbatas Produk, Revisi Produk akhir.

Alat peraga fisika sederhana yang dikembangkan sangat layak digunakan sebagai bahan ajar dan dapat memotivasi minat belajar peserta didik dan selain itu alat peraga fisika sederhana SMA juga memberi manfaat kepada pendidik yang belum menggunakan alat peraga. Dalam menyampaikan materi kepada peserta didik terciptanya keefektifan belajar dan meningkatkan minat belajar agar peserta didik dapat belajar mandiri dan lebih mudah menyerap materi yang dipelajari dan dapat meningkatkan mutu pendidikan.

Untuk mengetahui uji kelayakan alat peraga fisika menggunakan uji validasi ke beberapa ahli yaitu sebagai berikut:

1. Hasil validasi dilakukan oleh ahli materi dan ahli media. Hasil penilaian pada ahli materi mendapatkan persentase kelayakan 75,9\% dengan kategori "Baik". Hasil penilaian pada ahli media mendapatkan persentase kelayakan 83,68\% dengan kategori "Sangat Baik".

2. Hasil respon peserta didik SMA Negeri 1 Sidomulyo mendapatkan persentase kelayakan 83,925\% dengan kategori "Sangat Baik", untuk SMA Negeri 1 Candipuro mendapatkan persentase kelayakan $82,7 \%$ dengan kategori "Sangat Baik" dan untuk SMA Muhammadiyah 1 Sidomulyo mendapatkan persentase kelayakan $83,3 \%$ dengan kategori "Sangat Baik". Sedangkan untuk respon pendidik di tiga sekolah mendapatkan persentase 93\% dengan kategori "Sangat Baik". Hal ini menunjukkan bahwa alat peraga fisika sederhana yang dikembangkan sangat menarik bagi peserta didik maupun pendidik dan dapat digunakan sebagai salah satu media penunjang dalam pembelajaran.

\section{DAFTAR PUSTAKA}

Arsyad, A. (2003). Media Pembelajaran Jakarta: PT. Raja Grafindo Persada.

Djamharah, Zain, "Strategi Belajar Mengajar", Rineka Cipta, Jakarta, 2013.
Comment [U4]: Perbanyak referensi dari jurnal 
Emzir, "Metodologi Penelitian Pendidikan Kuantitatif \& Kualitatif Edisi Revisi”, PT. RajaGrafindo Persada, Jakarta, 2013.

Jumiati. (2016). Pembuatan alat praktikum termoskop guna menjelaskan radiasi kalor berbasis teknologi murah dan sederhana.

Kusrinaningrum, Y. P., Sutikno, \& Masturi. (2015). Pendingin Sederhana sebagai Alat Peraga untuk Memahami Perpindahan Panas. Seminar Nasional Fisika, IV, 187190.

Putro, Eko, "Teknik Penyusunan Instrumen Penelitian”, Pustaka pelajar, Yogyakarta, 2012.

Sugiyono,"Metode Penelitian Pendidikan; Pendekatan Kuantitatif, Kualitatif, dan R\&D”, Alfabeta, Bandung, 2014.

Suprayitno, Totok, "Pembuatan Alat Peraga Fisika Untuk SMA" Direktorat Pembinaan Sekolah Menengah Atas, 2011.

Supardianningsih, "Fisika Kelas XI Semester 2”, PT Intan Pariwara, Klaten, 2015.

Trianto, "Model Pembelajaran Terpadu", PT Bumi Aksara, Jakarta, 2012. 